\title{
NILA MERAH AIR TAWAR, PELUANG BUDIDAYANYA DI TAMBAK AIR PAYAU
}

\author{
Abdul Mansyur dan Markus Mangampa \\ Balai Riset Perikanan Budidaya Air Payau \\ Jl. Makmur Dg. Sitakka No. 129, Maros 90512, Sulawesi Selatan \\ E-mail: litkanta@yahoo.com
}

\begin{abstract}
ABSTRAK
Salah satu komoditas perikanan budidaya bernilai ekonomis tinggi adalah ikan nila merah (Oreochromis niloticus), merupakan ikan air tawar, yang miliki potensi untuk dibudidayakan di tambak air payau. Ikan nila merah merupakan ikan yang memiliki daya tahan tubuh dan adaptasi yang baik. Salah satu adaptasi yang dapat dilakukan oleh ikan nila adalah adaptasi fisiologis terhadap rentang salinitas yang tinggi karena ikan nila tergolong ikan eurihaline dan memiliki potensi untuk menyesuaikan diri pada salinitas air laut. Pembudidayaan ikan nila (Oreochromis niloticus) tergolong mudah dibandingkan pembudidayaan udang dan ikan kerapu. Risiko terkena penyakit atau hama pada ikan nila relatif lebih kecil dibandingkan dengan udang. Budidaya nila merah yang dipolikultur dengan udang vaname secara semi-intensif dapat meningkatkan pendapatan petani hingga mencapai Rp 20.200.000,-/musim (105-120 hari).
\end{abstract}

KATA KUNCI: nila merah, tambak air payau

\section{PENDAHULUAN}

Rancangan strategi Kementerian Kelautan dan Perikanan (KKP) periode 2010-2014 untuk meningkatkan produksi. Target peningkatan produksi ini termasuk dalam mega program yakni produksi perikanan budidaya pada tahun 2014 meningkat 353\%. Salah satu komoditas perikanan budidaya yang bernilai ekonomis tinggi adalah ikan nila merah.

Ikan nila merah merupakan ikan air tawar dan dikenal sebagai nila merah Taiwan atau hybrid antara Oreochromis hornorum dengan Oreochromis mossambicus yang diberi nama ikan nila merah Florida. Harliwati, 1996 dalam Cholik et al., 2005 mencatat bahwa ikan hibrid tersebut sebagai Oreochromis niloticus Trewavas, bahkan ada yang menduga bahwa nila merah merupakan mutan dari ikan mujair. Dimasukkan ke Indonesia dari Filipina pada tahun 1981 dan pada tahun 1989 dari Thailand, sekarang sudah berkembang kehampir seluruh wilayah Indonesia.

Selama ini pengembangan budidaya ikan nila merah di masyarakat tidak banyak menemui kesulitan karena nila merah merupakan salah satu jenis ikan yang potensial dikembangkan, budidayanya relatif mudah dengan pertumbuhan yang relatif cepat, membutuhkan biaya produksi (cost production) yang minim dibandingkan pembudidayaan udang dan ikan kerapu, risiko terkena penyakit atau hama pada ikan nila relatif lebih kecil dibandingkan dengan udang. Di samping itu, dapat dibudidayakan dengan spesies lain seperti polikultur nila merah dan udang vaname.

Produksi nila merah saat ini masih terbatas untuk memenuhi permintaan dalam negeri, baik untuk diversifikasi ikan budidaya maupun produksi untuk memenuhi gizi keluarga. Namun melihat prospek dan potensi yang ada, maka tidak menutup kemungkinan untuk dikembangkan secara profesional sehingga dapat dijadikan komoditas ekspor guna menambah devisa negara dari sub sektor perikanan.

Umumnya ikan nila merah dibudidayakan di perairan air tawar seperti danau dan sejenisnya dengan sistem keramba, namun beberapa tahun terakhir metode produksi ikan nila merah terus dikaji dan dikembangkan terutama dibudidayakan di tambak air payau.

\section{Nila Merah Menarik Dan Bergizi}

Ciri-ciri ikan nila merah yaitu badan agak bulat dan pipih, mulut terletak di ujung kepala, garis rusuk terputus menjadi dua bagian dan terletak memanjang dimulai dari atas sirip dada. Jumlah sisik garis rusuk sebanyak 34 buah, warnanya kemerahan polos atau bertotol-totol hitam, dan sering pula berwarna albino (bule). Sebagian pembudidaya kadang-kadang dijadikan sebagai ikan hias.

Ikan nila merah memiliki sejumlah keunggulan seperti harga yang cukup memadai sekitar Rp 15.000,-/kg dengan ukuran 250-350 g/ekor, dan kandungan proteinnya yang tinggi, rasa daging yang enak, mudah berkembang biak 
dan mampu beradaptasi pada kisaran yang lebar terhadap kondisi lingkungan karena ikan ini tergolong euryhalin (Cholik et al., 2005); tanggap terhadap pakan buatan, dan dapat dibudidayakan dengan spesies lain. Keunggulan ini membuat ikan nila merah relatif mudah diterima masyarakat karena memiliki peluang pasar yang sangat baik serta menjangkau semua segmen pasar.

Hasil analisis kandungan nutrisi nila merah pada tambak air payau yang berbeda dapat dilihat pada Tabel 1 . Dari Tabel 1 terlihat bahwa hasil analisis menunjukkan bahwa kandungan protein tertinggi didapatkan dari tambak percobaan Marana dibandingkan dengan yang didapatkan dari tambak percobaan Takalar. Perbedaan kandungan protein dan parameter lainnya antar lokasi dimungkinkan oleh perbedaan cara budidayanya. Pada tambak percobaan Takalar dilakukan budidaya secara semiintensif dengan menggunakan pakan komersil selama pemeliharaan. Sedangkan nila merah yang dibudidayakan di tambak percobaan Marana adalah teknologi ekstensif (tradisional), yaitu hanya mengandalkan pakan alami seperti plankton.

Tabel 1. Hasil analisis proksimat (\%) ikan nila merah pada tambak percobaan Takalar dan tambak Marana

\begin{tabular}{ccccccc}
\hline \multirow{2}{*}{ Lokasi } & \multicolumn{6}{c}{ Hasil proksimat (\%) } \\
\cline { 2 - 7 } & Air & Abu & Lemak & Protein & Serat kasar & BETN \\
\hline Takalar & 1,435 & 13,66 & 23,41 & 47,07 & 6,7 & 9,15 \\
Marana & 1,82 & 13,21 & 21,96 & 60,79 & 3,15 & 0,89 \\
\hline \multirow{2}{*}{ Rataan } & $\mathbf{1 , 6 2 7}$ & $\mathbf{1 3 , 4 3 5}$ & $\mathbf{2 2 , 6 8 5}$ & $\mathbf{5 3 , 9 3}$ & $\mathbf{4 , 9 3}$ & $\mathbf{5 , 0 2}$ \\
\hline
\end{tabular}

Sumber: Laboratorium penguji BRPBAP, Maros (2010)

\section{Peluang Budidaya di Air Payau}

Untuk pengembangan budidaya nila merah di tambak air payau benih diperoleh dari hasil pembenihan di air tawar. Benih tersebut membutuhkan aklimatisasi/adaptasi yang tepat yaitu menaikkan salinitas sebesar $5 \mathrm{ppt} / \mathrm{hari}$ sampai mencapai salinitas yang dikehendaki untuk selanjutnya ditebar ke tambak air payau (Suryati et al., 1991; Hasnidar, 1992). Teknik aklimatisasi dapat menggunakan rumus (Kenan, 1990 dalam Rahma \& Sahidhir, 2010).

$$
\mathrm{V} 1 \times \mathrm{M} 1=\mathrm{V} 2 \times \mathrm{M} 2
$$

di mana:

$\mathrm{V} 1=$ Volume air laut

M1 = Salinitas air laut (35 ppt)

$\mathrm{V} 2=$ Volume air tawar

M2 = Salinitas yang diinginkan
Misalnya salinitas yang diinginkan adalah $15 \mathrm{ppt}$ dan salinitas 30 ppt maka perbandingan percampuran air laut dengan air tawar untuk memperoleh media bersalinitas yang diinginkan setiap harinya seperti pada Tabel 2 .

Tabel 2. Perbandingan volume air laut : air tawar untuk mencapai salinitas yang diinginkan

\begin{tabular}{ccccc}
\hline Hari ke- & \multicolumn{2}{c}{$\begin{array}{c}\text { Salinitas yang } \\
\text { diinginkan (ppt) }\end{array}$} & \multicolumn{2}{c}{ Air laut : air tawar } \\
\hline 1 & 5 & 5 & $1: 6$ & $1: 6$ \\
2 & 10 & 10 & $2: 6$ & $2: 6$ \\
3 & 15 & 15 & $3: 6$ & $3: 6$ \\
4 & & 20 & & $4: 6$ \\
5 & & 25 & & $5: 6$ \\
6 & & 30 & & $6: 6$ \\
\hline
\end{tabular}

Sumber: Rahma \& Sahidhir (2010)

Sebelum nila merah (Gambar 1) dipindahkan ke tambak air payau sebaiknya didederkan terlebih dahulu pada bakbak terkontrol. Pendederan benih merupakan tahapan yang sangat penting agar diperoleh benih yang lebih besar dan bermutu baik serta lebih sehat untuk ditebar pada budidaya pembesaran. Dari hasil penelitian menunjukkan bahwa salinitas $0,10,20$, dan $30 \mathrm{ppt}$ tidak berbeda nyata terhadap sintasan nila merah tetapi berbeda nyata terhadap pertumbuhan (Mansyur \& Syamsuddin, 1997). Untuk pendederan menggunakan hapa di dalam tambak, kepadatan benih dianjurkan 300 ekor $/ \mathrm{m}^{2}$.

Langkah selanjutnya untuk pembesaran di tambak air payau meliputi persiapan tambak seperti, pengolahan tanah dasar dengan hand tractor, pengeringan tanah dasar, pemberantasan hama dengan menggunakan saponin dosis $20 \mathrm{mg} / \mathrm{L}$, dan pengapuran tanah dasar menggunakan dolomit $1.000 \mathrm{~kg} / \mathrm{ha}$. Pengisian air untuk persiapan klorinasi bertujuan menetralkan air dan tanah dasar dari bakteri patogen, dengan dosis klorin $>20 \mathrm{mg} / \mathrm{L}$. Dilakukan pemupukan dengan menggunakan pupuk organik dan anorganik untuk penumbuhan makanan alami, dan sesudah itu dilakukan peninggian air $>1,0 \mathrm{~m}$ untuk persiapan penebaran. Apabila pembesaran nila merah dipolikultur dengan spesies lain seperti rumput laut dan udang vaname maka yang didahulukan adalah penebaran rumput laut (Mangampa et al., 2010). Penebaran rumput laut dilakukan dengan metode apung menggunakan tali ris berjarak 1,0 m dengan jarak simpul 0,50 m. Setiap simpul diikatkan rumput laut sebanyak $50 \mathrm{~g}$ dengan ketinggian 0,75 $\mathrm{m}$ dari dasar. Setelah rumput laut mulai tumbuh, dilakukan penebaran nila merah masing-masing 6.500 ekor/ha. Selanjutnya dilakukan penebaran tokolan 

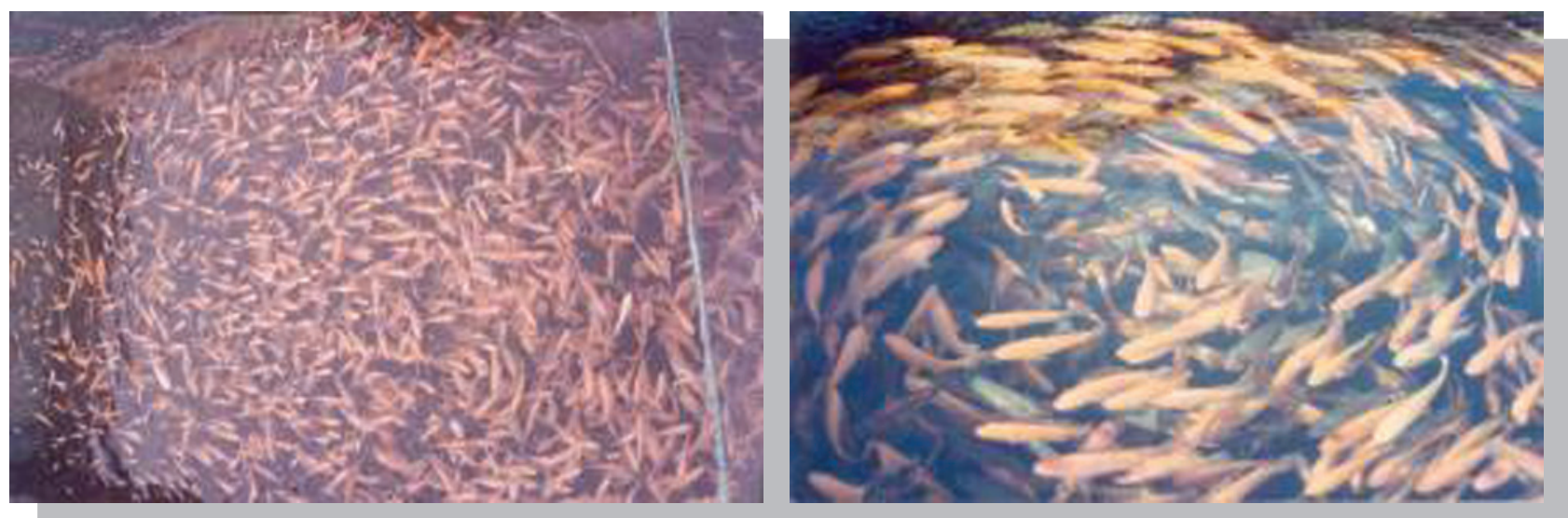

Gambar 1. Ikan nila merah yang siap dibesarkan di tambak air payau

udang vaname $>$ PL-27 (Mangampa et al., 2009) sebanyak 200.000 ekor/ha.

Pemantauan kualitas air perlu dilakukan, meliputi: suhu, salinitas, transparansi, $\mathrm{pH}$, dan kedalaman air setiap hari, sedangkan plankton, DO, alkalinitas, $\mathrm{NH}_{3}, \mathrm{H}_{2} \mathrm{~S}$, dan $\mathrm{PO}_{4}$ setiap 3-5 hari. Selain itu, juga dilakukan pemberian pupuk urea dan TSP susulan setiap minggu sebanyak 5\%$10 \%$ dari pupuk awal guna menjaga kestabilan plankton dalam tambak. Pengapuran susulan berupa dolomit super dilakukan apabila pengamatan terhadap $\mathrm{pH}$ memperlihatkan variasi yang tidak normal atau alkalinitas menurun. Penambahan air perlu dilakukan apabila berkurang sebanyak yang hilang akibat penguapan atau rembesan.

\section{Penggunaan Pakan Buatan}

Ikan nila merah adalah ikan omnivora. Di waktu muda ikan ini pemakan plankton, baik plankton nabati maupun hewani. Beranjak dewasa mulai makan detritus dan sering juga alga benang. Ikan nila merah juga tanggap terhadap pakan buatan (pelet). Formulasi pakan nila merah mudah dibuat dengan komposisi bahan penyusun seperti dedak halus $40 \%$, tepung ikan $20 \%$, tepung jagung $15 \%$, bungkil $10 \%$, tepung kedelai $10 \%$, minyak ikan secukupnya, dan akuamik secukupnya. Karena ikan nila merah tanggap terhadap pakan buatan seperti pelet maka pakan nila merah sudah banyak beredar di pasaran. Selama pemeliharaan dalam pendederan di hapa dalam tambak diberi pakan buatan berkadar protein 20\%-25\% sebanyak 2\%-3\% bobot badannya (Cholik et al., 2005). Ada dua jenis pakan pelet untuk pembesaran nila merah yang sudah beredar di pasaran yaitu pakan tenggelam dan pakan terapung. Hasil penelitian di keramba jaring apung (KJA) laut (Pongsapan et al., 1993), menunjukkan bahwa pakan tenggelam memberikan respons pertumbuhan, produksi, dan rasio konversi pakan yang lebih baik dibanding pakan terapung (Tabel 3).

Tabel 3. Produksi nila merah dengan pakan tenggelam dan terapung pada KJA laut

\begin{tabular}{lcc}
\hline \multirow{2}{*}{\multicolumn{1}{c}{ Variabel }} & \multicolumn{2}{c}{ Jenis pakan } \\
\cline { 2 - 3 } & Tenggelam & Terapung \\
\hline Bobot awal (g/ind.) & 23,50 & 35,00 \\
Bobot akhir (g/ind.) & 120,40 & 115,90 \\
Pertumbuhan mutlak (g/ind.) & 96,90 & 80,90 \\
Pertumbuhan harian (\%) & 1,50 & 1,10 \\
Sintasan (\%) & 80,00 & 78,30 \\
Jumlah pakan (kg/keramba) & 56,79 & 63,20 \\
Produksi (kg/keramba) & 23,26 & 19,01 \\
Rasio konversi pakan & 2,40 & 3,30 \\
\hline
\end{tabular}

Sumber: Pongsapan et al. (1993)

\section{Produksi dan Analisis Usaha}

Menurut Cholik et al. (2005), nila merah jantan mempunyai ukuran lebih besar dan laju pertumbuhan lebih cepat, sehingga banyak petani mengarahkan pada budidaya nila merah jantan. Oleh karena itu, para pakar budidaya perikanan telah berupaya menciptakan teknologi pembenihan nila merah jantan dengan menggunakan 60 mg hormone methyltestosteron yang dicampur dalam satu kilogram pakan larva. Proses alih kelamin tersebut berlangsung selama 28 hari (Subagyo et al., 1993 dalam Cholik et al., 2005). Selanjutnya dinyatakan bahwa nila merah jantan yang dipelihara dalam KJA laut dapat tumbuh mencapai bobot $400 \mathrm{~g}$ dari bobot awal $50 \mathrm{~g}$ dalam waktu pemeliharaan 3 bulan dan dapat hidup baik pada salinitas 32-35 ppt. 


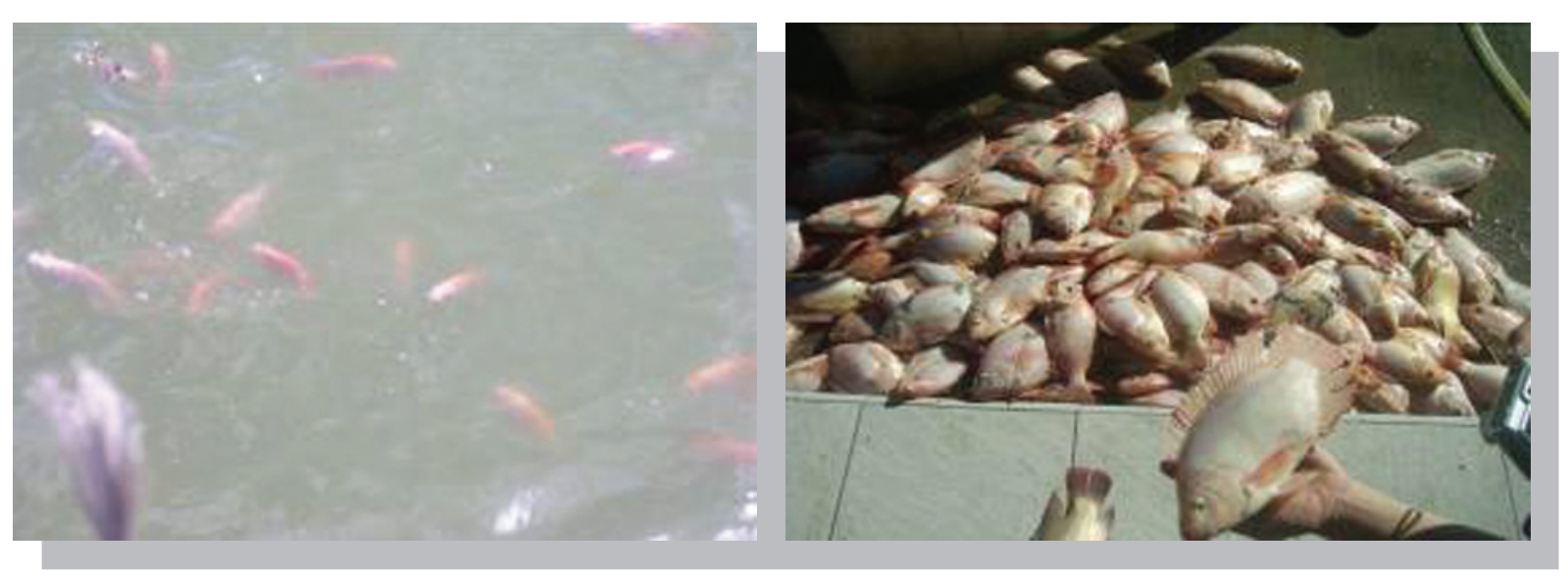

Gambar 2. Nila merah yang dipelihara (a); hasil panen nila merah dari tambak (b)

Pembesaran nila merah (Gambar 2) yang dipolikultur dengan udang vaname (Litopenaeus vannamei) dan rumput laut (Kappaphycus alvarezii) telah dicoba di tambak air payau secara semi-intensif dengan masa pemeliharaan 105120 hari. Hasil yang diperoleh menunjukkan produksi nila merah $1.272 \mathrm{~kg} / \mathrm{ha}$ dan udang vaname $2.192,5 \mathrm{~kg} / \mathrm{ha}$; dengan keuntungan yang diperoleh adalah $\mathrm{Rp}$ 20.200.000,-/musim (Tabel 4).

Dari Tabel 4 tidak menampakkan keberadaan rumput laut, Kappaphycus alvarezii yang di ujicoba dengan budidaya polikultur nila merah dan udang vaname di tambak. Hal ini disebabkan karena pada akhir penelitian tidak ditemukan lagi komoditas rumput laut Kappaphycus alvarezii. Hasil pengamatan menunjukkan bahwa pada bulan pertama sampai memasuki pertengahan bulan kedua (umur pemeliharaan 45 hari), rumput laut Kappaphycus alvarezii, memperlihatkan pertumbuhan yang baik namun sesudah umur pemeliharaan 45 hari, pertumbuhan menurun akibat aktivitas ikan nila merah, sehingga dalam

Tabel 4. Pertumbuhan, sintasan, produksi, dan rasio konversi pakan udang vaname, nila merah, dan rumput laut selama 105-120 hari pemeliharaan

\begin{tabular}{lcc}
\hline \multirow{2}{*}{ Parameter } & \multicolumn{2}{c}{ Perlakuan } \\
\cline { 2 - 3 } & Udang vaname & Nila merah \\
\hline Padat tebar (ekor/ha) & 200.000 & 6.500 \\
Bobot awal rata-rata (g/ekor) & $0,194 \pm 0,0208$ & $23 \pm 5,1813$ \\
Bobot akhir rata-rata (g/ekor) & $14,2 \pm 1,9608$ & $343,55 \pm 32,3070$ \\
Pertumbuhan mutlak (g/ekor) & $14,06 \pm 1,9608$ & $320,55 \pm 32,3070$ \\
Sintasan (\%) & 77,20 & 59,24 \\
Produksi (kg/ha) & $2.192,50$ & 1.272 \\
Rasio konversi pakan (RKP) & 1,57 & 1,32 \\
\hline
\end{tabular}

Sumber: Mangampa et al. (2010) perhitungan penjualan belum dimasukkan (Mangampa et al., 2010). Selanjutnya dinyatakan bahwa penggunaan rumput laut, Kappaphycus alvarezii untuk komoditas tambak, perlu dikaji penempatannya dalam tandon tambak intensif yang cukup dalam sebagai biofilter tanpa biofilter lain sebagai pemangsa rumput laut selain itu, waktu panen rumput laut perlu diperhatikan.

Analisis finansial polikultur nila merah, udang vaname, dan rumput laut (Mangampa et al., 2010) terdapat pada Lampiran.

\section{KESIMPULAN}

1. Nila merah yang biasanya dibudidayakan di air tawar ternyata dapat juga dibudidayakan di air bersalinitas tinggi.

2. Budidaya nila merah di tambak (salinitas 23-32 ppt) ternyata dapat dipolikultur dengan rumput laut dan udang vaname.

3. Dari analisis finansial polikultur nila merah, rumput laut, dan udang vaname dapat meningkatkan pendapatan pembudidaya tambak sebesar $\mathrm{Rp}$ 20.200.000,-/ha/musim.

4. Karena nila merah diperoleh dari pembenihan air tawar diperlukan pengetahuan dasar tentang teknik adaptasi.

5. Sebelum nila merah dipindahkan ke tambak air payau sebaiknya didederkan terlebih dahulu pada bak-bak terkontrol. Pendederan benih merupakan tahapan yang sangat penting agar diperoleh benih yang lebih besar dan bermutu baik serta lebih sehat untuk ditebar pada budidaya pembesaran.

\section{DAFTAR ACUAN}

Cholik, F., Jagatraya, A.G., Poernomo, R.P., \& Jauzi, A. 2005. Akuakultur tumpuan harapan masa depan 
bangsa. Diterbitkan atas kerja sama Masyarakat Perikanan Nusantara dengan Taman Akuarium Air Tawar, Taman Mini Indonesia Indah, Jakarta, 415 hlm.

Hasnidar. 1992. Pengaruh waktu peningkatan salinitas saat pengeraman telur dan pemeliharaan larva terhadap kelangsungan hidup dan pertumbuhan ikan nila merah (hibrid O. niloticus). Tesis Program Pasca Sarjana Universitas Hasanuddin, Ujung Pandang.

Mangampa, M., Tahe, S., \& Suwoyo, H.S. 2009. Riset budidaya udang vaname tradisional plus menggunakan benih tokolan dengan ukuran yang berbeda. Makalah Konferensi Akuakultur Indonesia 2009. MAI, Yogyakarta, $11 \mathrm{hlm}$.

Mangampa, M., Suharyanto, \& Suwoyo, H.S. 2010. Polikultur udang windu (Penaeus monodon), udang vaname (Litopenaeus vannamei), nila merah (Oreochromis niloticus), dan rumput laut (Kappaphycus alvarezii) secara semi-intensif. Laporan hasil penelitian Balai Riset Perikanan Budidaya Air Payau, Maros, $12 \mathrm{hlm}$.
Mansyur, A. \& Syamsuddin, R. 1997. Tingkat kelangsungan hidup dan pertumbuhan ikan nila merah (hibrid 0 . niloticus) pada salinitas berbeda. Torani, Bulletin Penelitian Ilmu Kelautan, 7(1): 23-28.

Pongsapan, D.S., Tonnek, S., Kabangnga, N., \& Usman. 1993. Pengaruh pakan tenggelam dan terapung terhadap produksi ikan nila merah, 0 . niloticus dalam keramba jaring apung di laut.J. Pen. Budidaya Pantai, 9(4): 75-84.

Rahma, A. \& Sahidhir, I. 2010. Pengaruh perbedaan salinitas terhadap pertumbuhan benih nila merah (Oreochromis sp.). http://artaquaculture.blogspot.com/ 2010/09 (Akses 11 Januari 2011).

Suryati, Y., Pranowo, S.A., Ismail, I., \& Wardoyo, S.E. 1991. Pengaruh tingkat pemberian pakan yang berbeda terhadap pertumbuhan ikan nila merah (hybrid $T$. nilotica) di Teluk Banten. Bul. Pen. Perik. Puslitbang Perikanan, 3: 123-134. 
Lampiran

A. Investasi

1. Sewa lahan: 1 ha/tahun @ Rp 3.000.000,-

2. Pompa air: - Pompa alcon 6 inci 1 unit

- Kincir air (1 HP) 2 unit

$$
\text { Jumlah }
$$

\begin{tabular}{lr}
$R p$ & $3.000 .000,-$ \\
$R p$ & $10.000 .000,-$ \\
$R p$ & 9.000 .000 ,- \\
\cline { 2 - 2 } Rp & $\mathbf{2 2 . 0 0 0 . 0 0 0},-$
\end{tabular}

B. Biaya tetap (Fixed cost $=$ FC)

\begin{tabular}{|c|c|c|c|c|}
\hline Komponen & Investasi & $\begin{array}{l}\text { Usia eco. } \\
\text { (tahun) }\end{array}$ & $\begin{array}{l}\text { Fixed Cost/ tahun } \\
(\mathrm{Rp})\end{array}$ & $\begin{array}{l}\text { Fixed Cost/musim } \\
\text { (Rp) }\end{array}$ \\
\hline Sewa lahan: 1 ha /tahun & 3.000 .000 & 1 & 3.000 .000 & 1.500 .000 \\
\hline \multicolumn{5}{|l|}{ Peralatan: } \\
\hline - Pompa alcon 6 inci 1 unit & 10.000 .000 & 5 & 2.000 .000 & 1.000 .000 \\
\hline \multirow[t]{2}{*}{ - Kincir air 2 unit } & 9.000 .000 & 3 & 3.000 .000 & 1.500 .000 \\
\hline & 22.000 .000 & & 8.000 .000 & 4.000 .000 \\
\hline
\end{tabular}

C. Biaya operasional (Variable Cost $=\mathrm{VC}$ )

\begin{tabular}{lccr}
\hline \multicolumn{1}{c}{ Komponen } & Satuan & Unit cost (Rp) & Total cost (Rp) \\
\hline 1. - Benur vaname (ekor/ha) & 200.000 & 31,5 & 6.300 .000 \\
- Nila merah (ekor/ha) & 6.500 & 300 & 1.950 .000 \\
- Benih rumput laut, tali, dan lain-lain & 500 & 2.400 & 1.200 .000 \\
2. - Pakan udang (kg) FCR 1,57 & 3.450 & 12.000 & 41.400 .000 \\
- Pakan ikan (kg) FCR 1,32 & 1.680 & 5.000 & 8.400 .000 \\
3. Kaptan/dolomit (kg) & 1.000 & 900 & 900.000 \\
4. Pupuk anorganik (kg) & 200 & 2.000 & 400.000 \\
5. Pupuk organik (40 kg/sak) & 800 & 1.000 & 800.000 \\
6. Saponin (kg) & 50 & 6.000 & 300.000 \\
7. Solar (L) & 200 & 4.500 & 900.000 \\
8. Oli (L) & 10 & $25.000,-$ & 250.000 \\
9. Tenaga kerja : 1 orang (6 bln) & $/$ musim & $600.000,-$ & 3.600 .000 \\
10. Maintenance petakan & pm & $500.000,-$ & 500.000 \\
11. Transportasi (ret) & 2 & $350.000,-$ & 700.000 \\
12. Biaya panen & pm & - & 1.000 .000 \\
13. Lain-lain & pm & - & 500.000 \\
14. Bunga bank (6\%/tahun) & $6 \mathrm{bln}$ & - & 2.750 .000 \\
\hline & & & 71.850 .000 \\
\hline
\end{tabular}

D. Total cost $(\mathrm{FC}+\mathrm{VC})$

- Biaya modal/musim

- Biaya variabel/musim :

$$
\text { Jumlah }
$$

\begin{tabular}{lr}
$R p$ & 4.000 .000 \\
$R p$ & 71.850 .000 \\
\cline { 2 - 2 } & ,- \\
& $\mathbf{7 5 . 8 5 0 . 0 0 0},-$
\end{tabular}

E. Penjualan :

Udang vaname : $2.200 \mathrm{~kg} @ \mathrm{Rp} 35.000$,-

Nila merah : 1.270 kg@ Rp 15.000,-

$$
\text { Jumlah }
$$

$\begin{array}{ll}R p & 77.000 .000,- \\ R p & 19.050 .000,- \\ & 96.050 .000,-\end{array}$

F. Keuntungan/Kerugian

$$
\begin{aligned}
& \text { - Penjualan } \\
& \text { - Total Biaya }
\end{aligned}
$$

\begin{tabular}{ll}
$R p$ & 96.050 .000 \\
$R p$ & 75.850 .000 \\
\cline { 2 - 2 } & $\mathbf{2 0 . 2 0 0 . 0 0 0},-$
\end{tabular}

